\title{
MODIFICATION OF BIOCHEMICAL PROPERTIES BY SOIL USE*
}

\section{Carmen Trasar-Cepeda ${ }^{1}$, María Carmen Leirós ${ }^{2}$, Fernando Gil-Sotres ${ }^{2}$}

${ }^{1}$ Departamento de Bioquí mica del Suelo, Instituto de Investigaciones Agrobiológicas de Galicia-Consejo Superior de Investigaciones Científicas (CSIC), Apartado 122, E-15780 Santiago de Compostela, España. Corresponding authors: ctrasar@iiag.csic.es

${ }^{2}$ Departamento de Edafología y Química Agrícola, Facultad de Farmacia, Campus Sur, Universidad de Santiago de Compostela, E-15782 Santiago de Compostela, España.

\section{Modificación de las propiedades bioquímicas por el uso del suelo}

Key words: Soil enzymes, soil biochemical properties, soil use, soil management, forest soils, agricultural soils.

\begin{abstract}
Human activity is one of the main causes of the physical, chemical and biological degradation of soils. This degradation implies a change in soil quality as it involves both a decrease in productivity and changes in the ecological functions of the soil. The objective of the present study was to investigate the effect of soil use on soil biochemical properties, with the aim of providing data that allow assessment of the usefulness of enzymatic activities as indicators of soil quality. In addition to physical and chemical properties, different hydrolase enzymes involved in the C, N, P and S cycles, and other biochemical properties, such as the microbial biomass $\mathrm{C}$ and soil basal respiration, were analysed. The results obtained allowed different conclusions to be reached regarding the main processes involving the biochemical properties in soils affected by human activity.
\end{abstract}

\footnotetext{
*The present study is a summary of a wider paper to be Publisher in Soil Biology and Biochemistry. This was presented as a Keynote to the $3^{\text {rd }}$ International Conference on Soil Enzymes (Viterbo, Italy), 15-19 july 2007 and, partly, as a invited Conference to the Segundo Simposio Internacional: Suelo, Ecologí a y Medioambiente (Temuco, Chile), 8-9 noviembre 2007.
} 
Palabras clave: Enzimas del suelo, propiedades bioquímicas del suelo, uso del suelo, manejo del suelo, suelos forestales, suelos agrícolas

\section{RESUMEN}

La actividad humana es una de las principales causas de la degradación física, química y biológica de los suelos. Dicha degradación implica un cambio en la calidad del suelo, ya que supone tanto una disminución en la productividad como cambios en las funciones ecológicas del suelo. El objetivo del presente estudio fue investigar el efecto del uso del suelo sobre las propiedades bioquímicas, con el fin de proporcionar datos que permitan estimar la utilidad de las actividades enzimáticas como indicadores de la calidad del suelo. Además de las propiedades físicas y químicas de los suelos, se analizaron diferentes hidrolasas implicadas en los ciclos del C, N, P y S, así como otras propiedades bioquímicas tales como el carbono asociado a la biomasa microbiana o la respiración basal del suelo. Los resultados obtenidos permitieron obtener diversas conclusiones en relación a los principales procesos que afectan a las propiedades bioquímicas en los suelos afectados por la actividad humana.

\section{INTRODUCTION}

Human activity is the main cause of the physical, chemical and biological degradation of soils (Leita et al 1999). Such degradation implies a loss of soil quality, manifested by a decrease in the productive capacity and alterations in the ecological functions of the soil (Granadtstein and Bezdicek, 1992). It is therefore necessary to determine the extent to which soil use affects soil quality and of course, the parameters used to estimate the quality. Biochemical properties are usually considered as the best indicators of soil quality because of their sensitivity to external agents and also because they are easy to measure. Among these, the activities of hydrolytic enzymes involved in the cycling of bio- elements (C, N, P and S) are often selected for the estimation of soil quality. Although there exists a great deal of information about the effect of soil use on enzymatic activities, in many cases the results published by different authors are inconsistent. Thus, for the same use and/or agricultural practice, there may be an increase, or decrease in the soil biochemical activity, or even no effect at all. This is true, for example, for the frequency of harvesting, which has been reported to cause an increase in biochemical activity due to the greater amount of dead root remains (Holland, 1995, Mawdsley and Bardgett, 1997), a decrease in biochemical activity due to the decreased root exudates (Northup et al 1999), and also to have no effect on biochemical activity (Wardle and Barker, 1997, Kuzyakov et al 2002). In summary, the effects of soil use and management on soil biochemical properties are highly contradictory. This brings into doubt whether biochemical properties, and in particular enzymatic activities, actually provide an indication of how management affects the soil, and therefore whether these properties should be used as indicators of soil quality. On the other hand, the contradictory results may be the consequence of another series of factors such as the different analytical methods used to determine the enzymatic activities, the small number of soils analysed in most cases, or the fact that the soils have different properties.

The aim of the present study was to compare data on soils subject to different types of use (obtained by our research group over the course of several years) in order to 
find out whether biochemical properties in general, and enzyme activities in particular, are suitable indicators of alterations in soil quality in relation to soil use. The starting hypothesis was to consider that as natural soils under climax vegetation (climax soils) have developed in equilibrium they are therefore soils of maximum quality and display the greatest degree of balance in their properties (Fedoroff, 1987). It was also considered that soil use will alter the biochemical properties, thereby affecting this balance.

\section{MATERIAL AND METHODS}

The soils under study were from Galicia (NW Spain), a region characterized by a humid climate (mean annual temperature between 12 and $15{ }^{\circ} \mathrm{C}$, mean annual precipitation between 1000 and $1700 \mathrm{~mm}$ ). The samples included $40 \mathrm{Ah}$ horizons of soils developed under climax vegetation of Atlantic oak, mainly Quercus robur L. and in some cases Quercus pyrenaica L. Another 78 soils from reforested land were analysed, of which 43 corresponded to soils developed under stands of Pinus, mainly Pinus pinaster Aiton, although some of the soils were under $P$. sylvestris L. and $P$. radiata $\mathrm{D}$. Don. The soils under climax vegetation and also the reforested soils were Umbrisols (ISSS Working Group, 1998). Fifty six grassland soils were also analysed; these included grassland with a low intensity of management and other highly fertilized soils, to which organic fertilizers (mainly cow slurry and sometimes pig slurry) and also inorganic fertilizers had been applied. The soils were Umbrisols and in topographically depressed areas, Gleysols (ISSS Working Group, 1998). Finally, 60 agricultural soils were analysed, 45 of which were cropped soils under maize. These soils represented soils subjected to traditional agricultural practices, under crops that have been grown in a similar way for several centuries, with bi or tri annual rotation of crops and application of inorganic and organic (manure) fertilizers. The samples studied were collected after crops were harvested, and before tillage or treatment, to avoid any effect that these practices and/or the application of agrosanitary products may have on the soil biochemical activity. The other 15 soils were vineyard soils, which were generally heavily degraded and located on steep terraced slopes. The soils (Regosols, ISSS Working Group, 1998) were collected in February, a time of year when no treatments or soil preparation are carried out in vineyards. Reports have already been published describing the biochemical properties of these agricultural soils (Miguéns et al 2007, Trasar-Cepeda et al 2008) and of climax soils (Leirós et al 2000; Trasar-Cepeda et al., 2000).

All of the samples were collected from the upper $10-15 \mathrm{~cm}$ of the soil after removal of the litter layer in the forest soils, the very dense layer of roots in the grassland soils and the harvesting remains (when present) in the maize soils. In all cases, between 15 and 20 subsamples were collected and combined in the field to make composite samples, then transported to the laboratory and sieved through a $4 \mathrm{~mm}$ sieve. The samples were then stored at $4{ }^{\circ} \mathrm{C}$ until analysis of the biochemical properties, always within 15 days; a subsample was also air dried and, when required, finely ground before analysis of the physical, chemical and physico-chemical properties. All of the soil samples were analysed to determine the activity of the different hydrolase enzymes involved in the $\mathrm{C}, \mathrm{N}, \mathrm{P}$ and $\mathrm{S}$ cycles: CM-cellulase, B-glucosidase and invertase from the $\mathrm{C}$ cycle; caseinhydrolysing protease (casein-protease), N-benzoil-L-arginine-amide-hydrolysing protease (BAA-protease) and urease from the N cycle; phosphodiesterase (Diesterase) and phosphomonoesterase (Monoesterase) from the P cycle and finally, arylsulphatase from the $\mathrm{S}$ cycle. Other soil properties related to the number and activity of soil microorganisms were also analysed: the microbial biomass $\mathrm{C}$ (Biomass-C) and the soil basal respiration. The metabolic coefficient $\left(q \mathrm{CO}_{2}\right)$, i.e. the respiration per 
Table 1: Mean values of the general properties for each group of soils. For each property, the letter $a$ indicates that the mean value differs significantly $(P \leq 0.01)$ from that corresponding to the climax soils.

Cuadro 1: Valores promedios de las propiedades generales para cada grupo de suelos. Para cada propiedad, la letra $a$ indica que el valor promedio difiere significativamente $(P \leq 0.01)$ de aquel correspondiente a los suelos climax.

\begin{tabular}{lcccccr}
\hline & Vineyard & Maize & Grassland & Eucalyptus & Pine & Climax \\
\hline pH KCl & $4.12 a$ & $4.57 a$ & $4.15 a$ & $3.76 a$ & $3.78 b$ & $3.48 b$ \\
Total C (\%) & $1.52 a$ & $3.16 a$ & $4.78 a$ & $6.74 a$ & $7.84 a$ & $10.75 b$ \\
Total N (\%) & $0.12 a$ & $0.25 a$ & $0.37 a$ & $0.41 a$ & $0.44 a$ & $0.66 b$ \\
$\mathbf{C} / \mathbf{N}$ & $13 a$ & $12 a$ & $13 a$ & $17 b$ & $18 b$ & $17 b$ \\
$\mathbf{A l}_{\mathbf{2}} \mathbf{O}_{\mathbf{3}}(\%)$ & $0.21 a$ & $0.56 a$ & $0.58 a$ & $1.25 b$ & $1.19 b$ & $1.08 b$ \\
$\mathbf{F e}_{2} \mathbf{O}_{\mathbf{3}}(\%)$ & $0.22 a$ & $0.41 a$ & $0.60 a$ & $0.59 a$ & $0.6 a$ & $0.96 b$ \\
$\mathbf{A v a i l a b l e ~ P i ~}^{\mathbf{a}}$ & $116 a$ & $126 a$ & $39 a$ & $9 a$ & $8 a$ & $20 b$ \\
Sand (\%) & $71 a$ & $60 a$ & $52 b$ & $52 b$ & $52 b$ & $51 b$ \\
Clay (\%) & $12 a$ & $15 a$ & $20 b$ & $18 b$ & $18 b$ & $20 b$ \\
\hline
\end{tabular}

a inorganic $\mathrm{P}$, in $\mathrm{mg} \mathrm{kg}^{-1}$

unit of biomass and unit of time, was also calculated. The enzyme activities and the other biochemical properties were determined following the protocols described by different authors and explained in detail by García et al (2003). Finally, all of the soils were characterized in terms of their main physical, chemical and physicochemical properties $(\mathrm{pH}$ in $\mathrm{KCl}$, total $\mathrm{C}$ and $\mathrm{N}$, amorphous $\mathrm{Fe}$ and $\mathrm{Al}$ oxides, available inorganic $\mathrm{P}$ and particle size distribution) following the protocols described by Guitián and Carballas (1976).

\section{RESULTS AND DISCUSSION}

\section{General soil properties}

The mean values of the general properties of each group of soils are shown in Table 1. It can be seen that the soils under different types of use are of similar texture, although the vineyard and maize soils contain larger amounts of sand and lower of clay than the others. Soil use resulted in increased $\mathrm{pH}$ and $\mathrm{P}$ content, particularly in agricultural soils. Nevertheless the soils are generally strongly acidic, which suggests that the liming was not very intense. On the contrary the enrichment in $\mathrm{P}$ was acute, indicating intensive use of phosphate fertilizers. Soil use also resulted in a large loss of organic matter. Tus in reforested soils the organic C content was between 60 and $70 \%$ that of the climax soils, and in the agricultural soils the organic $\mathrm{C}$ content was only between 10 and $40 \%$, with the vineyard soils displaying the lowest values. The decrease in total nitrogen was not as acute: the reforested soils contained between 60 and $70 \%$ of the amount in the climax soils (similar percentages to those obtained for organic C), whereas in the agricultural soils the percentage of $\mathrm{N}$ was between 20 and $60 \%$ that of the climax soils, which indicates intense application of nitrogen fertilizers. 
Table 2: Mean values of the enzymatic activities studied for each group of soils. For each property, the letter $a$ indicates that the mean value differs significantly $(P \leq 0.01)$ from that corresponding to the climax soils.

Cuadro 2: Valores promedios de las actividades enzimáticas para cada grupo de suelos. Para cada propiedad, la letra $a$ indica que el valor promedio difiere significativamente $(P \leq 0.01)$ de aquel correspondiente a los suelos climax.

\begin{tabular}{lcccccc}
\hline & Vineyard & Maize & Grassland & Eucalyptus & Pine & Climax \\
\hline CM-cellulase $^{\mathbf{a}}$ & $0.05 a$ & $0.09 a$ & $0.20 b$ & $0.24 b$ & $0.23 b$ & $0.23 b$ \\
B-glucosidase $^{\mathbf{b}}$ & $0.45 a$ & $0.72 a$ & $1.45 b$ & $1.74 b$ & $1.82 b$ & $1.55 b$ \\
Invertase $^{\mathbf{a}}$ & $1.28 a$ & $2.60 a$ & $6.03 b$ & $4.18 a$ & $6.16 b$ & $6.85 b$ \\
Casein-protease $^{\mathbf{c}}$ & $0.29 a$ & $0.73 a$ & $1.23 a$ & $1.04 b$ & $1.28 a$ & $0.94 b$ \\
BAA-protease $^{\mathbf{d}}$ & $4.61 a$ & $7.1 a$ & $19.6 b$ & $15.7 b$ & $17.0 b$ & $15.3 b$ \\
Urease $^{\mathbf{d}}$ & $1.9 a$ & $4.3 a$ & $17.7 b$ & $12.1 b$ & $16.9 b$ & $16.6 b$ \\
Diesterase $^{\mathbf{b}}$ & $0.12 a$ & $0.32 a$ & $0.64 a$ & $1.62 a$ & $1.58 a$ & $0.96 b$ \\
Monoesterase $^{\mathbf{b}}$ & $1.22 a$ & $2.58 a$ & $4.86 a$ & $7.45 b$ & $8.43 b$ & $6.62 b$ \\
Arylsulphatase $^{\mathbf{b}}$ & $0.03 a$ & $0.15 a$ & $0.43 b$ & $0.28 a$ & $0.31 a$ & $0.46 b$ \\
\hline
\end{tabular}

${ }^{\mathrm{a}} \mu \mathrm{mol}$ glucose $\mathrm{g}^{-1} \mathrm{~h}^{-1} ;{ }^{\mathrm{b}} \mu \mathrm{mol} p$-nitrophenol g-1 $\mathrm{h}^{-1} ;{ }^{\mathrm{c}} \mu \mathrm{mol}$ tyrosine $\mathrm{g}^{-1} \mathrm{~h}^{-1} ;{ }^{\mathrm{d}} \mu \mathrm{mol} \mathrm{NH} \mathrm{g}^{-1} \mathrm{~h}^{-1}$

The decrease in organic matter in turn caused a decrease in the content of extractable $\mathrm{Al}$ and $\mathrm{Fe}$ oxides.

\section{Activity of hydrolytic enzymes}

The mean values of the activity of hydrolytic enzymes in each group of soils are shown in Table 2. In the soils subject to the most intensive use (maize and vineyard) the values were much lower than those obtained for climax soils. However, for the reforested and grassland soils the values were lower, similar to or even higher than those corresponding to the climax soils. In the maize soils, the enzymatic activity was on average $42 \%$ that of the climax soils, whereas in the vineyard soils, it was only $24 \%$ that of the climax soils. In the maize soils, the enzyme that displayed the lowest activity in comparison with that in the climax soils was urease, which may be explained by the absence of macrofauna in these ecosystems; in the vineyard soils, arylsulphatase was the enzyme that displayed the lowest activity in relation to that in the climax soils, possibly as a consequence of the use of antifungal products containing sulphate. The enzymes that displayed values of activity most similar to those in the climax soils were caseinprotease in the maize soils and BAAprotease in the vineyard soils. As regards the other groups of soils, i.e. the reforested and the grassland soils, for the $\mathrm{C}$ cycle enzymes, CM-cellulase and invertase displayed similar values in the grassland and reforested soils to those corresponding to the climax soils (except invertase under eucalyptus), and for $\beta-$ glucosidase the values in pine and eucalyptus soils were clearly higher than in the climax soils and those in grassland soils slightly lower. The activities of the $\mathrm{N}$ cycle enzymes (casein-protease, BAA- 
protease and urease) were always higher in reforested soils (except urease in soils under eucalyptus) and in grassland soils than in the climax soils, particularly for caseinprotease and BAA-protease. As regards the $\mathrm{P}$ cycle, except for phosphomonoesterase in the grassland soils, in the other cases the values were always higher, and in the reforested and grassland soils, sometimes almost double those in the climax soils. Finally, as regards the only $\mathrm{S}$ cycle enzyme determined (arylsulphatase) the values in both the reforested and grassland soils were lower than in the climax soils. In summary, it is clear that the statement "soil use decreases enzyme activity" (often considered as an axiom in reviews of the effect of soil use on biochemical properties) is not correct, but rather depends on the type of use or management as well as on the enzyme under consideration. However, it is true that those enzymatic activities normally considered to be inhibited by fertilizers (e.g. phosphomonoesterase) display lower activities in fertilized soils than in climax soils.

Table 3: Mean values of the enzymatic activities per unit of carbon for each group of soils. For each property, the letter $a$ indicates that the mean value differs significantly $(P \leq 0.01)$ from that corresponding to the climax soils.

Cuadro 3: Valores promedios de las actividades enzimáticas por unidad de carbono para cada grupo de suelos. Para cada propiedad, la letra $a$ indica que el valor promedio difiere significativamente $(P \leq 0.01)$ de aquel correspondiente a los suelos climax.

\begin{tabular}{|c|c|c|c|c|c|c|}
\hline & Vineyard & Maize & Grassland & Eucalyptus & Pine & Climax \\
\hline$\overline{C M-c e l l u l a s e} / \mathbf{C}^{\mathrm{a}}$ & $3.1 b$ & $2.9 b$ & $4.8 a$ & $3.7 a$ & $2.9 a$ & $2.1 b$ \\
\hline B-glucosidase/ $\mathbf{C}^{\mathbf{b}}$ & $30 a$ & $24 a$ & $33 a$ & $27 a$ & $24 a$ & $15 b$ \\
\hline Invertase $/ \mathbf{C}^{\mathrm{a}}$ & $84 b$ & $86 a$ & $129 a$ & $63 b$ & $82 b$ & $67 b$ \\
\hline Casein-protease/ $\mathbf{C}^{\mathrm{c}}$ & $19 a$ & $25 a$ & $27 a$ & $16 a$ & $17 a$ & $10 b$ \\
\hline BAA-protease/C ${ }^{\text {d }}$ & $317 a$ & $227 a$ & $435 a$ & $236 a$ & $219 a$ & $148 b$ \\
\hline Urease $/ \mathbf{C}^{\mathbf{d}}$ & $123 b$ & $134 b$ & $381 a$ & $178 b$ & $213 b$ & $159 b$ \\
\hline Diesterase $/ \mathbf{C}^{\mathbf{b}}$ & $8 b$ & $11 b$ & $14 a$ & $26 a$ & $20 a$ & $9 b$ \\
\hline Monoesterase $/ \mathbf{C}^{b}$ & $85 b$ & $84 b$ & $110 a$ & $115 a$ & $107 a$ & $63 b$ \\
\hline Arylsulphatase/C $\mathbf{C}^{\mathbf{b}}$ & $1.8 a$ & $4.8 b$ & $9.0 a$ & $4.4 b$ & $4.0 b$ & $4.6 b$ \\
\hline
\end{tabular}

${ }^{\mathrm{a}} \mu \mathrm{mol}$ glucose $\mathrm{g}^{-1} \mathrm{Ch}^{-1} ;{ }^{\mathrm{b}} \mu \mathrm{mol} p$-nitrophenol $\mathrm{g}^{-1} \mathrm{Ch}^{-1} ;{ }^{\mathrm{c}} \mu \mathrm{mol}$ tyrosine $\mathrm{g}^{-1} \mathrm{Ch}^{-1} ;{ }^{\mathrm{d}} \mu \mathrm{mol} \mathrm{NH} \mathrm{g}^{-1} \mathrm{Ch}^{-1}$ 
Enzymatic activities per unit $C$

When the mean values of activity were expressed in relation to $\mathrm{C}$ (specific activity) for each group of soils (Table 3), it was found that the mean values of activity were always higher in soils affected by human activity than in climax soils. This was true except for arylsulphatase/C and CMcellulase/C for which, in all soils (except the grassland soils) the mean values were very similar to those corresponding to the climax soils. For the other enzymes the differences were very large, particularly for the grassland soils. Thus, for the $\mathrm{C}$ cycle enzymes, the mean activity of ß-glucosidase and invertase per unit $C$ in the grassland soils was almost double that in the climax soils and for the other soils, the values were approximately one and a half times higher. For the $\mathrm{N}$ cycle enzymes, except for urease in the maize and vineyards soils, the same occurred as with the C cycle enzymes: the specific activity values were almost twice as high in the grassland soils, and one and a half times higher in the reforested soils than in the climax soils. For the $\mathrm{P}$ cycle enzymes the highest values of specific activity corresponded to the reforested soils, and the values in the vineyard and maize soils were similar to those in the climax soils. For the only S cycle enzyme analysed, arylsulphatase, the values of activity per unit $\mathrm{C}$ were similar among groups of soils although, in the vineyard soils the mean value was low and in the grassland soils the mean value was extremely high.

In conclusion, soil use causes an important loss of organic matter and a smaller loss or an increase in enzymatic activity. The logical result of these variations is a higher quantity of enzymatic activity per unit $C$. In other words, soil use causes a relative increase in enzymatic activity. The interpretation of this enrichment is complex, as on one hand it may represent an ecological mechanism to protect the soil metabolic activity (Burns, 1982), clearly at risk due to the progressive loss of organic matter and fundamentally of the most labile organic matter (Janzen et al, 1992, Ogle et al, 2005) or it may be the result of metabolic stress of the soil microbiota in response to agricultural activities (Doran, 1980).

As regards the latter possibility, the values of soil basal respiration and of microbial biomass $\mathrm{C}$ were always lower in the soils under different types of use than in the climax soils and in addition, the reductions in respiration and biomass-C were always of the same order (Table 4), which means that the values of $q \mathrm{CO}_{2}$, except those

Table 4: Mean values of microbial biomass $\mathrm{C}$, basal respiration and $q \mathrm{CO}_{2}$ obtained for each group of soils. For each property, the letter $a$ indicates that the mean value differs significantly $(P \leq 0.01)$ from that corresponding to the climax soils.

Cuadro 4: Valores promedios de la biomasa microbiana y respiración basal $q \mathrm{CO}_{2}$ obtenida de cada grupo de suelos. Para cada propiedad, la letra $a$ indica que el valor promedio difiere significativamente $(P \leq 0.01)$ de aquel correspondiente a los suelos climax.

\begin{tabular}{lcccccc}
\hline & Vineyard & Maize & Grassland & Eucalyptus & Pine & Climax \\
\hline Biomass-C $^{\mathbf{a}}$ & $57 a$ & $201 a$ & $493 a$ & $437 a$ & $519 a$ & $781 b$ \\
Basal respiration $^{\mathbf{b}}$ & $72 a$ & $161 a$ & $358 a$ & $268 a$ & $342 a$ & $615 b$ \\
$\boldsymbol{q C O}{ }^{\mathbf{c}}$ & $9.7 a$ & $3.6 b$ & $3.4 b$ & $2.8 b$ & $3.0 b$ & $3.5 b$ \\
\hline
\end{tabular}

${ }^{\mathrm{a}} \mathrm{mg} \mathrm{kg}^{-1} ;{ }^{\mathrm{b}} \mathrm{mg} \mathrm{CO}{ }_{2}-\mathrm{C}$ emitted kg ${ }^{-1} 10 \mathrm{~d}^{-1} ;{ }^{\mathrm{c}} \mu \mathrm{g} \mathrm{CO}_{2}-\mathrm{C} \mathrm{mg}^{-1}$ biomass-C ${ }^{-1}$ 
obtained for vineyard soils (in which the microbiota was highly stressed due to the intensity of the agricultural practices to which the soils were subject) were very similar to each other and almost identical to the mean value obtained for the climax soils (Table 4). In other words, the fact that the value of $q \mathrm{CO}_{2}$ did not change suggests (Dalal, 1998) that soil use does not have a direct effect on the metabolic activity of the microorganisms, and these will not be the main cause of the observed enrichment in enzyme activity. The increase in enzyme activity in the soils subject to use must be due to a process of stabilization of enzyme activity. However, with the data available it is not possible to determine the mechanisms by which the stabilization is produced. Therefore, in order to establish the accuracy of using soil enzyme activities as indicators of soil quality, further studies are required to elucidate the mechanisms of enzyme stabilization in relation to intensity of soil use.

\section{CONCLUSIONS}

Soil use causes a clear decrease in organic matter content; however, the enzymatic activity does not always follow this trend, and may increase or decrease. Independently of soil use, the values of the enzymatic activity per unit of carbon are higher in the soils subject to use than in climax soils, which indicate that soil use favours stabilization of the enzymatic activity in soil.

\section{ACKNOWLEDGEMENT}

This study was financed by the Xunta de Galicia (Project No. XUGA 40003B94) and by the MCYT (Project No. BTE 20010987). The authors thank Ana I. IglesiasTojo, Carolina López-Cotón, Tamara Migué ns, Jorge Paz-Ferreiro and Diana Bello for their assistance in carrying out the analyses.

\section{REFERENCES}

BURNS, R.G., 1982. Enzyme activity in soil: location and possible role in microbial ecology. Soil Biology \& Biochemistry 14, 423-427.

DALAL, R.C., 1998. Soil microbial biomass - what do the numbers really mean?. Australian Journal of Experimental Agriculture 38, 649665.

DORAN, J.W., 1980. Soil microbial and biochemical changes associated with reduced tillage. Soil Science Society of America Journal 44, 765-771.

FEDOROFF, N., 1987. The production potential of soils. Part 1. Sensitivity of principal soil types to the intensive agriculture of north-western Europe, in: E. Barth, P. L'Hermite: Scientific Basis for Soil Protection in the European Community. Elsevier Press, London, pp. 65-86.

GARCÍ A， C., GIL-SOTRES, F., HERNÁNDEZ, M.T., TRASARCEPEDA, C., 2003. Té cnicas de Análisis de Pará metros Bioquímicos en Suelos: Medida de Actividades Enzimáticas y Biomasa Microbiana. Madrid, ed. Mundi-Prensa, 371 p.

GUITIÁN OJEA, F., CARBALLAS, T., 1976. Técnicas de análisis de suelos. Santiago de Compostela, ed. Pico Sacro, 288 p.

GRANATSTEIN, D., BEZDICEK, D.F., 1992. The need for a soil quality index: Local and regional perspectives. American Journal of Alternative Agriculture 7, 12-16

ISSS WORKING GROUP R.B., 1998. World Reference Base for Soil Resources: Introduction. First edition. ISSS- ISRIC-FAO. Acco, Leuven, $165 \mathrm{p}$. 
HOLLAND, J.N., 1995. Effects of aboveground herbivory on soil microbial biomass in conventional and no-tillage agroecosystem. Applied Soil Ecology 2, 275-279.

JANZEN, H.H., CAMPBELL, C.A., BRANDT, S.A., LAFOND, G.P., TORONLEY-SMITH, L., 1992. Lightfraction organic matter in soils from long-term crop rotations. Soil Science Society of America Journal 56, 17991806

KUZYAKOV, Y., BIRYUKOVA, O.V., KUZNETZOVA, T.V., MÖLTER, K., KANDELER, E., STAHR, K., 2002. Carbon partitioning in plant and soil, carbon dioxide fluxes and enzyme activities as affected by cutting ryegrass. Biology and Fertility of Soils $35,348-358$.

LEIRÓS, M.C., TRASAR-CEPEDA, C., SEOANE, S., GIL-SOTRES, F., 2000. Biochemical properties of acid soils under climax vegetation (Atlantic oakwood) in an area of the European temperate-humid zone (Galicia, NW Spain): general parameters. Soil Biology \& Biochemistry 32, 733-745.

LEITA, L., DE NOBILI, L.L., M O N D I C I N I, M ., MUHLBACHOVA, G., MARCHIOL, L., BRAGATO, G., CONTIN, M., 1999. Influence of organic and inorganic fertilization on soil microbial biomass, metabolic quotient and heavy metal bioavailability. Biology and Fertility of Soils 28, 371-376.

MAWDSLEY, J.L., BARDGETT, R.D., 1997. Continuous defoliation of perennial ryegrass (Lolium perenne) and white clover (Trifolium repens) and associated changes in the microbial population of an upland grassland soil. Biology and Fertility of Soils 27, 969975.
MIGUÉNS, T., LEIRÓS, M.C., GILSOTRES, F., TRASAR-CEPEDA, C., 2007. Biochemical properties of vineyard soils from Galicia, Spain. The Science of the Total Environment 378, 218-222.

NORTHUP, B.K., BROWN, J.R., HOLT, J.A., 1999. Grazing impacts on the spatial distribution of soil microbial biomass around tussock grasses in a tropical grassland. Applied Soil Ecology 13, 259-270.

OGLE, S.M., BREIDT, F.J., PAUSTIAN, K., 2005. Agricultural management impacts on soil organic carbon storage under moist and dry climatic conditions of temperate and tropical regions. Biogeochemistry 72, 87-121.

TRASAR-CEPEDA, C., LEIRÓS, M.C., GIL-SOTRES, F., 2000. Biochemical properties of acid soils under climax vegetation (Atlantic oakwood) in an area of the European temperate-humid zone (Galicia, NW Spain): specific parameters. Soil Biology \& Biochemistry 32, 747-755.

TRASAR-CEPEDA, C., LEIRÓs, MC., SEOANE, S., GIL-SOTRES, F., 2008. Biochemical properties of soils under crop rotation. applied Soil Ecology 39, 133-143.

WARDLE, D.A., BARKER, G.M., 1997. Competition and herbivory in establishing grassland communities: implications for plant biomass, species diversity and soil microbial activity. Oikos 80, 470-480. 